University of South Carolina

Scholar Commons

$2-1982$

Campaign Contributions and Congressional Voting: $\mathrm{A}$

Simultaneous Probit-Tobit Model

Henry W. Chappell Jr.

University of South Carolina - Columbia, chappell@moore.sc.edu

Follow this and additional works at: https://scholarcommons.sc.edu/econ_facpub

Part of the Economics Commons

Publication Info

Review of Economics and Statistics, Volume 64, Issue 1, 1982, pages 77-83.

http://www.mitpressjournals.org/loi/rest

(C) 1982 by The MIT Press

This Article is brought to you by the Economics Department at Scholar Commons. It has been accepted for inclusion in Faculty Publications by an authorized administrator of Scholar Commons. For more information, please contact digres@mailbox.sc.edu. 


\title{
CAMPAIGN CONTRIBUTIONS AND CONGRESSIONAL VOTING: A SIMULTANEOUS PROBIT-TOBIT MODEL
}

\author{
Henry W. Chappell, Jr.*
}

\section{Introduction}

$\mathbf{M}$ ANY citizens and scholars have been troubled by the influence that special interest groups appear to exert over policymaking as a result of their roles in the financing of political campaigns. These concerns inspired the enactment of a number of election law reforms in the 1970s, and have led to increasing popular support for public financing of electoral campaigns. Despite the public attention these issues have attracted, few social scientists have attempted to analyze the financial relationships between interest groups and policymakers empirically. ${ }^{1}$ One such study was reported by Durden and Silberman (1976), who included contributions from the AFL-CIO political action committee as an independent variable in an equation explaining congressional voting on minimum wage legislation. Their results indicated that campaign contributions significantly affected voting on that issue. The work I have done differs substantially from that of Durden and Silberman in two ways. First, I have chosen to examine issues which were of considerably narrower concern than the minimum wage issue. In the interest of simplicity, I examine issues of concern to just one or a few groups. I have also used a different econometric technique. If campaign contributions are actually endogenous (as seems plausi-

Received for publication December 29, 1980. Revision accepted for publication May 27, 1981.

* University of South Carolina.

This paper is based on my Ph.D. dissertation in economics. I wish to acknowledge the valuable suggestions of my advisors, Susan Rose-Ackerman and Ray C. Fair. Comments from an anonymous referee have improved the exposition of several points.

1 A number of previous econometric works have dealt with various aspects of campaign finance or roll-call voting. See, for example, Jackson (1974), Welch (1974, 1980), Palda (1975), Durden and Silberman (1976), Jacobson (1978), Abrams (1977), Danielson and Rubin (1977), and Kau and Rubin (1979). Only the article by Durden and Silberman examines the connection between funding and subsequent voting. In recent works, Kau, Keenan, and Rubin (1979) and Welch (forthcoming) have independently undertaken studies of contributions and voting, but they have employed econometric approaches which differ from the simultaneous equations model developed here. ble), the single equation estimation technique employed by Durden and Silberman is subject to a possible simultaneous equations bias. For each issue studied, I have therefore jointly estimated a two equation system explaining both votes on the bill and contributions from an associated interest group. The "simultaneous probit-Tobit" model which I use takes into account the dichotomous nature of the variable indicating a congressman's vote, the non-negativity constraint imposed on the contribution variable, and the possibility of correlation between the error terms for the equations explaining these two variables. ${ }^{2}$ Full-information maximum likelihood (FIML) estimates for the model are consistent and asymptotically efficient.

\section{The Model}

In the analysis of voting on a particular issue, the principal economic agents of concern are congressmen and a single interest group. ${ }^{3}$ Congressmen's voting decisions are presumed to be motivated by a desire to be reelected, while the interest group is assumed to allocate campaign funds to various candidates in an attempt to influence the legislative outcome of the issue. In (1)-(5) below, I hypothesize a "simultaneous probit-Tobit" model (hence referred to as model SPT) to explain voting decisions made by congressmen and contribution decisions made by the interest group:

$$
\begin{aligned}
& y_{1 i}=\gamma w_{2 i}+\beta_{1} X_{1 i}-v_{1 i} \\
& y_{2 i}=\beta_{2} X_{2 i}-\sigma_{2} v_{2 i} \\
& w_{1 i}=\left\{\begin{array}{l}
1 \text { if } y_{1 i}>0 \\
0 \text { if } y_{1 i} \leq 0
\end{array}\right. \\
& w_{2 i}=\left\{\begin{array}{l}
y_{2 i} \text { if } y_{2 i}>0 \\
0 \text { if } y_{2 i} \leq 0
\end{array}\right.
\end{aligned}
$$

2 The model I use belongs to the general class of models described by Heckman $(1976,1978)$; however, the specific model I use has not been previously estimated. Some related models are discussed in Chappell (1981).

${ }^{3}$ A more detailed formal presentation of the theory is provided in Chappell (1979), which is based in part on the work of Rose-Ackerman (1978). 


$$
\begin{aligned}
E\left(v_{j i}\right)= & 0 ; E\left(v_{j i}^{2}\right)=1 ; E\left(v_{1 i} v_{2 i}\right)=\rho ; \\
& E\left(v_{j i} v_{j^{\prime} i^{\prime}}\right)=0 ; \text { for } j, j^{\prime}=1,2 ; \\
& i, i^{\prime}=1, \ldots, n ; i \neq j
\end{aligned}
$$

where

$y_{1 i}=\mathrm{a}$ latent variable indicating the propensity of a congressman to vote in favor of the interest group position;

$w_{1 i}=$ a dummy variable equal to 1 to indicate a "yes" vote (i.e., in favor of the interest group's favored alternative), and equal to 0 for a "no" vote;

$y_{2 i}=$ a latent variable indicating the propensity of the interest group to contribute to congressman $i$;

$w_{2 i}=$ the actual contribution from the interest group to congressman $i$;

$X_{1 i}$ is a vector of variables indicating constituency characteristics and the fixed attributes of congressman $i$;

$X_{2 i}$ is a vector of variables indicating the legislative power of congressman $i$ if he is elected, his probability of election, and his initial position on the issue;

$\beta_{1}, \beta_{2}$ are vectors of coefficients;

$\sigma_{2}, \gamma$ are scalar coefficients;

$v_{1}, v_{2}$ are random error terms.

It is assumed that $v_{1 i}$ and $v_{2 i}$ have a bivariate normal distribution with correlation coefficient $\rho$, and that restrictions sufficient to identify equation (1) are imposed.

The probit equation, (1), is hypothesized to explain votes on the issue. ${ }^{4}$ According to the model, a "yes" vote occurs when the unobserved latent variable $y_{1 i}$ exceeds a threshold level of zero, and a "no" vote occurs otherwise. This unobserved variable can be interpreted as the candidate's "propensity to vote in favor of the interest group.",

Equation (1) indicates that the propensity to favor the interest group is a function of contributions from the interest group and a vector of exogenous variables. It is useful to imagine that the exogenous variables determine an "initial

\footnotetext{
${ }^{4}$ Problems encountered in using the linear probability model when the dependent variable is dichotomous are well known: predicted values of the dependent variable are not limited to the 0 to 1 interval, and the errors are heteroscedastic and non-normal. Johnson (1972) has discussed the single equation probit model.
}

position" on the issue for a candidate, and that contributions cause shifts away from that position. The theoretical motivation for this formulation is straightforward. To increase his chances of election, a candidate will attempt to reflect the interests of constituents in his policy positions; thus constituent characteristics are included in the vector $X_{1 i}$. In a political world characterized by imperfect knowledge, he need not reflect those preferences perfectly to avoid certain electoral loss, however. Personal ideological preferences and party planks (also included in $X_{1 i}$ ) will affect his voting as well. Imperfect voter knowledge also allows campaign spending to aid in securing votes, so a congressman might be willing to alter his advocated policy somewhat if a campaign contribution were offered as an inducement. Voting could also be affected by contributions in more subtle ways. Alexander (1972), for example, has argued that contributions might induce a sympathetic response in a congressman which may not even be apparent to the recipient himself, and Welch (forthcoming) has likened the contribution-voting relationship to the reciprocal giving of Christmas gifts. The formulation of equation (1) is consistent with candidate responses to contributions which reflect tradeoffs to increase chances of election, as well as those which reflect induced sympathy for one's supporters.

Interest group contributions are explained by the Tobit equation, (2). ${ }^{5}$ Positive contributions are observed when an unobserved "propensity to contribute to a candidate," $y_{2 i}$, exceeds 0 . When the propensity to contribute is positive, actual contributions equal the propensity to contribute; when the propensity to contribute is negative, a zero contribution is observed.

An important assumption about the interest group $^{6}$ underlies the specification of the equation

\footnotetext{
${ }^{5}$ The simple linear model would alșo be inappropriate for an equation to explain contributions. Observed contributions are always greater than or equal to zero, but predicted values of contributions obtained from ordinary least squares (OLS) estimates can be negative. Since more than half of the observed contributions equal zero for each of the issues studied, failure to impose the non-negativity constraint on predicted contributions could imply a serious misspecification of the model. See Tobin (1958) for a discussion of the single equation Tobit model.

${ }^{6}$ By assuming just one interest group, I rule out complications which would arise if several groups were competing to achieve different outcomes.
} 
to explain contributions. I assume that in attempting to secure favorable policy by making contributions, the interest group regards candidates' probabilities of election as fixed. Both intuition and some empirical evidence suggest that this assumption is a good approximation of reality. Although aggregate candidate expenditures may have some effect on election chances, a contribution from any particular group will probably have negligible impact. ${ }^{7}$ Given that the group regards election probabilities as fixed, its motive for contributing must be to alter candidate policies via their reactions as specified in equation (1). ${ }^{8}$ (Welch (1974) has referred to this aim as the "quid pro quo" motive.) Contributions should therefore be targeted at powerful congressmen (e.g., veteran members of important committees) and at likely winners (e.g., incumbents). Influencing a candidate will be of little benefit if he has poor chances of gaining a seat in the legislature, or if he has no political clout once elected. The nature of majority voting processes also encourages contributors to try to build winning sized coalitions. Since coalitions are more easily built around a nucleus of supporters, we expect to see more contributions given to those with some initial tendency to favor the interest group rather than to those strongly inclined to oppose them. Thus contributions will be a function of $X_{2 i}$, a vector of variables indicating the legislative power of candidate $i$ conditional upon his election, his probability of election, and his initial position on the issue of concern. In the following empirical analysis, the variables in $X_{1 i}$ are employed as indicators of a congressman's initial position, thus $X_{1 i}$ is a subset of $X_{2 i}$.

Model SPT differs from standard probit and Tobit models only by permitting a non-zero correlation coefficient for the error terms of the equations. So long as $\rho=0$, single equation techniques could be used to estimate both equations (1) and (2) consistently. If $\rho \neq 0$, however, the

\footnotetext{
7 The econometric results of Jacobson (1978) show that even aggregate expenditures by incumbents (who make up a large proportion of the sample I use) have little or no effect on the percentage of votes won.

${ }^{8}$ Based on an econometric investigation, Welch (1980, p. 115 ) concluded that "an interest group contributes in order to obtain political favors, not to affect electoral outcomes." This is not inconsistent with the earlier assertion that politicians may desire contributions to further their election aims, since politicians may be considering the aggregate effects of all of their contributions.
}

error term $v_{1 i}$ will generally be correlated with the endogenous explanatory variable $w_{2 i}$ in equation (1). When an explanatory variable is correlated with the error term, the single equation probit estimator is subject to a bias similar to that arising in OLS estimation of a linear model under similar circumstances (see Olsen, 1975). This bias could result in very misleading conclusions. For example, suppose we analyze voting on appropriations for the B-1 bomber, but no measure of "hawkishness" is included as an exogenous variable in either equation (1) or (2). If Rockwell International (the prime contractor for the aircraft) contributed only to "hawks," hoping to ensure their election, and if these hawks later voted in favor of the B-1 bomber because they vote in favor of all military spending, then a correlation between contributions and votes would result. The relationship would not be causal, however, and reported significance of the contribution coefficient would be attributable to the correlation of error terms resulting from the omission of a variable. Use of a simultaneous equations estimator is therefore appropriate.

FIML estimates can be obtained for all parameters of model SPT, including the correlation coefficient $\rho$. These estimates are consistent and asymptotically efficient, and therefore avoid the problems inherent with the single equation probit estimators. A brief discussion of computational matters is presented in an appendix which is available from the author upon request.

The proposed model is necessarily a simplification of the real politico-economic world, and brief mention should be made of several important real world complications. We have assumed that congressmen's votes are independent of each other, yet in the real world interdependence may result from logrolling or from the emulation of leaders. The model also supposes that interest groups are rewarded for contributing, but it makes no provision for punishment of those who contribute to a congressman's enemies. In addition, candidates and interest groups may interact through channels which the model does not consider: an interest group may contribute by offering an illegal bribe or an in-kind contribution of labor; congressmen can respond via committee activities. Contributor motives may also be more complex. Contributions might be used to establish a reward structure which serves as a means of communication about the kind of behavior 
expected of recipients, or interest groups might give to friendly candidates in hopes that their campaigning will sway voter opinion in favor of the group. Perhaps more importantly, the model has assumed that the contribution decision is a unilateral one, made by the contributor alone. I have not accounted for endogenous candidate solicitation efforts, or for the possibility that candidates can turn down offered contributions. Despite these deficiencies, the model does provide a reasonable framework for analyzing voting decisions, and similar models have had some success in explaining congressional voting. Development of models incorporating more real world features provides a task for future research.

\section{The Empirical Study}

The preceding theoretical discussion provides a basis for the empirical analysis of interest group campaign contributions and roll call voting by members of the U.S. House of Representatives in the 1974-1977 period. Several criteria were used to guide the selection of the seven issues analyzed in the study. First, an effort was made to avoid issues of concern to numerous diverse and competing interest groups. Ideally, just one group should be associated with each issue. Issues in regulatory policy often conform to this criterion reasonably well, since a regulated industry usually provides a unified interest, and their opponents are diffuse and unorganized. I have also attempted to select issues for which close votes were recorded in the House, since congressmen may behave differently in their decision-making when voting on issues of certain versus those of doubtful outcomes. Issues for which a congressman must seriously consider the possibility that his vote could influence the ultimate outcome of legislation are preferred. Finally, it was also necessary to choose issues for which an associated interest group made substantial contributions.

The seven issues chosen for study include mortgage disclosure requirements for lenders, milk price supports, truck weight limits, tax rebates for oil companies, funding for the B-1 bomber, auto emissions controls, and a maritime cargo preference bill. The first three issues were voted on in 1975 and have been analyzed in conjunction with contribution data from the 1974 election, while the remaining four issues were voted on in 1977 and have been used with contribution data from the 1976 election. Table 1 briefly describes the legislative content of the seven issues, lists associated campaign contributors and their preferred policies, and indicates what variables are employed in the empirical study to represent constituent preferences on the bill. It also reports some summary statistics, including the number of congressmen in the sample receiving contributions from each group, and the aggregate value of those contributions. The number of congressmen for and against the interest group's favored alternative are also listed, as is the simple correlation coefficient between group contributions to individual congressmen and the dummy variable indicating a congressman's vote. In all cases the vote variable is defined so that votes favoring the interest group are assigned a value of one, thus positive correlations were anticipated. The table shows that for all eight contributors, contributions and associated votes were positively correlated.

The selection of explanatory variables to be included in the empirical analysis was guided by the discussion in section II. For an equation explaining votes on a given issue, the explanatory variables included contributions from the associated interest group, a dummy variable to indicate party affiliation, and an ideological rating, $A C A$. $A C A$ is a conservative rating computed by the Americans for Constitutional Action, and was included not only as an indicator of a congressman's personal ideological bent, but also as a measure of constituency preferences (since conservative constituents do tend to elect conservative representatives). In addition, other variables appropriate to specific issues were included, when available, as indicators of constituent preferences (see table 1). ${ }^{9}$ For equations explaining contributions from interest groups, explanatory variables included dummy variables for relevant committee memberships (as indi-

${ }^{9}$ A detailed list of variable definitions is available from the author upon request. Sources of data include The Almanac of American Politics, Common Cause's 1974 Congressional Campaign Finances and 1976 Federal Campaign Finances, The Congressional District Data Book. Congressional Quarterly Almanac, Congressional Quarterly Weekly Review, 1976 House of Representatives Receipts and Expenditures (Federal Elections Commission), Vessel Entrances and Clearances (Bureau of the Census), and the Basic Petroleum Data Book (American Petroleum Institute). 
Tabi.e 1.-Summary Statistics

\begin{tabular}{|c|c|c|c|c|c|}
\hline Issue /Sample a & Effect of Proposal & $\begin{array}{l}\text { Interest Group } \\
\text { Contributions }\end{array}$ & $\begin{array}{l}\text { Interest } \\
\text { Group } \\
\text { Position }\end{array}$ & $\begin{array}{l}\text { Vote- } \\
\text { Contribution } \\
\text { Correlation } \\
\text { Coefficient }\end{array}$ & $\begin{array}{l}\text { Indicators of Constituent } \\
\text { Preferences }\end{array}$ \\
\hline $\begin{array}{l}\text { 1. Red-lining Disclosure } \\
\text { Amendment } \\
\text { House Vote } 487,1975 \\
\text { Sample Size: } 328 \\
\text { Favoring Group: } 164 \\
\text { Opposing Group: } 164\end{array}$ & $\begin{array}{l}\text { Would ease proposed } \\
\text { requirements for detailed } \\
\text { reporting of the geographic } \\
\text { distribution of mortgage loans. }\end{array}$ & $\begin{array}{l}\text { American Banking Association: } \\
\$ 40,550 \text { to } 48 \text { Congressmen }\end{array}$ & Favored & .0748 & Urban population percentage \\
\hline $\begin{array}{l}\text { 2. Milk Price Supports } \\
\text { House Vote } 45,1975 \\
\text { Sample Size: } 417 \\
\text { Favoring Group: } 196 \\
\text { Opposing Group: } 221\end{array}$ & $\begin{array}{l}\text { Would reduce the proposed } \\
\text { milk price support level from } \\
85 \% \text { to } 80 \% \text { of parity. }\end{array}$ & $\begin{array}{l}\text { Associated Milk Producers, } \\
\text { Dairymen Incorporated: } \\
\$ 124,585 \text { to } 58 \text { Congressmen }\end{array}$ & Opposed & .1873 & $\begin{array}{l}\text { Dummy variable indicating } \\
\text { dairy farming importance in } \\
\text { a district: } \\
\text { Rural farm population } \\
\text { percentage }\end{array}$ \\
\hline $\begin{array}{l}\text { 3. Truck Weight Limits } \\
\text { House Vote } 600,1975 \\
\text { Sample Size: } 412 \\
\text { Favoring Groups: } 276 \\
\text { Opposing Groups: } 136\end{array}$ & $\begin{array}{l}\text { Would roll back maximum } \\
\text { truck weights allowed on } \\
\text { interstate highways from } 80,000 \\
\text { lb. to } 73.289 \mathrm{lb} \text {. }\end{array}$ & $\begin{array}{l}\text { American Trucking } \\
\text { Association: } \$ 79,500 \text { to } 131 \\
\text { Congressmen: } \\
\text { Teamsters: } \$ 79.834 \text { to } 90 \\
\text { Congressmen }\end{array}$ & Opposed & .0255 & \\
\hline $\begin{array}{l}\text { 4. Cargo Preference Bill } \\
\text { House Vote } 618,1977 \\
\text { Sample Size: } 420 \\
\text { Favoring Group: } 164 \\
\text { Opposing Group: } 256\end{array}$ & $\begin{array}{l}\text { Would require } 9.5 \% \text { of Amer- } \\
\text { ica's oil imports to be shipped } \\
\text { in U.S. built and operated } \\
\text { ships. }\end{array}$ & $\begin{array}{l}\text { Maritime Unions: } \$ 358,004 \text { to } \\
164 \text { Congressmen }\end{array}$ & Favored & .3737 & $\begin{array}{l}\text { Per capita tons entering ports } \\
\text { in a congressman's state }\end{array}$ \\
\hline $\begin{array}{l}\text { 5. Crude Oil Tax Rebate } \\
\text { House Vote 474, } 1977 \\
\text { Favoring Group: } 197 \\
\text { Opposing Group: } 222\end{array}$ & $\begin{array}{l}\text { Would return part of the } \\
\text { revenues from the proposed } \\
\text { crude oil equalization tax to } \\
\text { producers who make additional } \\
\text { investments in oil exploration. }\end{array}$ & $\begin{array}{l}\text { Major Oil Companies: } \$ 159,232 \\
\text { to } 190 \text { Congressmen }\end{array}$ & Favored & .4393 & $\begin{array}{l}\text { Per capita oil production in } \\
\text { a congressman's state }\end{array}$ \\
\hline $\begin{array}{l}\text { 6. Auto Emissions Standards } \\
\text { House Vote } 266,1977 \\
\text { Sample Size: } 389 \\
\text { Favoring Group: } 202 \\
\text { Opposing Group: } 187\end{array}$ & $\begin{array}{l}\text { Would impose stricter } \\
\text { emissions standards for } \\
\text { automobiles. }\end{array}$ & $\begin{array}{l}\text { National Automobile Dealers } \\
\text { Association: } \$ 192,250 \text { to } 187 \\
\text { Congressmen }\end{array}$ & Opposed & .2523 & $\begin{array}{l}\text { Dummy variable indicating } \\
\text { auto mobile manufacturing } \\
\text { importance in a district }\end{array}$ \\
\hline $\begin{array}{l}\text { 7. B-1 Bomber Appropriation } \\
\text { House Vote } 484,1977 \\
\text { Sample Size: } 419 \\
\text { Favoring Group: } 207 \\
\text { Opposing Group: } 212\end{array}$ & $\begin{array}{l}\text { Would delete funding for } \\
\text { production of } 5 \text { B-1 bombers. }\end{array}$ & $\begin{array}{l}\text { Rockwell International } \\
\text { Corporation: } \$ 7,800 \text { to } 35 \\
\text { Congressmen }\end{array}$ & Opposed & .1840 & \\
\hline
\end{tabular}

The sample for each issue consists of all congressmen voting on the issue, with the exception of those appointed to fill vacancies occurring since the previous election.

cators of power), a dummy variable for incumbency (to indicate likelihood of election), the candidate's vote percentage in the preceding election (also an indicator of likelihood of election), ${ }^{10}$ and exogenous variables from the equation explaining votes to serve as proxies for a candidate's initial position.

For each issue, model SPT was estimated by two techniques. First, under the assumption that $\rho=0$, single equation probit and Tobit estimators were employed. The more general model, which allows $\rho$ to take non-zero values, was then estimated by the FIML method. For the truck weight limits issue it was necessary to estimate the model twice, once considering only American Trucking Association contributions,

${ }^{10}$ If the candidate's vote percentage is actually endogenous, contrary to the assumption of the model, further econometric difficulties arise. In addition to the obvious simultaneity problem, estimates reported here would be subject to a selectivity bias, since only winning candidates (i.e., those with a vote percentage above $50 \%$ ) are included in the sample. and once considering only Teamster contributions. Separate analysis of the two groups was required since my program to compute FIML estimates of model SPT is limited to two equation systems.

Space limitations preclude the reporting of complete results here, ${ }^{11}$ so I will first summarize those findings which are similar according to the two techniques, and then turn to a discussion of the estimated effects of contributions, which are reported in table 2 .

In the probit equations explaining voting, the results consistently showed that ideology, party affiliation, and indicators of constituent interests are important determinants of congressmen's voting decisions. According to both single equation and simultaneous equation estimates, the coefficient of $A C A$, the ideological rating, was significant at the $1 \%$ level for 6 of 7 issues, and the coefficient of PARTY, a dummy variable in-

\footnotetext{
11 Complete results are available from the author upon request.
} 
Table 2.-Estimated Contribution Coefficients and Error Term Correlation Coefficients in Equations to EXPLAIN VOTING (asymptotic $t$-statistics are in parentheses)

\begin{tabular}{|c|c|c|c|}
\hline Issue/Group & $\begin{array}{l}\text { Single Equation } \\
\text { Probit }\end{array}$ & $\begin{array}{l}\text { FIML } \\
\text { Probit }\end{array}$ & $\begin{array}{c}\text { Error Term } \\
\text { Correlation Coefficient }\end{array}$ \\
\hline $\begin{array}{l}\text { 1. Red-lining Disclosure } \\
\text { American Banking Association }\end{array}$ & $\begin{array}{c}0.2739 \\
(0.7912)\end{array}$ & $\begin{array}{c}0.1783 \\
(0.3148)\end{array}$ & $\begin{array}{c}0.0669 \\
(0.2186)\end{array}$ \\
\hline $\begin{array}{l}\text { 2. Milk Prices } \\
\text { Dairy Groups }\end{array}$ & $\begin{array}{l}0.2416 \\
(2.3428)^{\mathrm{b}}\end{array}$ & $\begin{array}{c}0.0635 \\
(0.5868)\end{array}$ & $\begin{array}{l}0.3231 \\
(2.1665)^{\mathrm{b}}\end{array}$ \\
\hline $\begin{array}{l}\text { 3. Truck Weight Limits } \\
\text { Trucking Association }\end{array}$ & $\begin{array}{l}0.4558 \\
(2.3428)^{\mathrm{b}}\end{array}$ & $\begin{array}{c}0.0192 \\
(0.0654)\end{array}$ & $\begin{array}{l}0.2874 \\
(2.0264)^{\mathrm{b}}\end{array}$ \\
\hline $\begin{array}{l}\text { 4. Truck Weight Limits } \\
\text { Teamsters }\end{array}$ & $\begin{array}{c}0.2572 \\
(1.6168)\end{array}$ & $\begin{array}{c}0.1902 \\
(0.5977)\end{array}$ & $\begin{array}{c}0.0538 \\
(0.2742)\end{array}$ \\
\hline $\begin{array}{l}\text { 5. Crude Oil Tax Rebate } \\
\text { Oil Companies }\end{array}$ & $\begin{array}{l}0.2822 \\
(1.6994)^{\mathrm{c}}\end{array}$ & $\begin{array}{l}-0.2906 \\
(-0.8027)\end{array}$ & $\begin{array}{l}0.4080 \\
(1.8318)^{\mathrm{c}}\end{array}$ \\
\hline $\begin{array}{l}\text { 6. Auto Emissions Standards } \\
\text { National Automobile Dealers Assoc. }\end{array}$ & $\begin{array}{l}0.3309 \\
(3.1053)^{\mathrm{a}}\end{array}$ & $\begin{array}{l}-0.1814 \\
(-0.9623)\end{array}$ & $\begin{array}{l}0.4965 \\
(3.5425)^{\mathrm{a}}\end{array}$ \\
\hline $\begin{array}{l}\text { 7. B-1 Bomber Appropriation } \\
\text { Rockwell International }\end{array}$ & $\begin{array}{l}6.2879 \\
(3.7243)^{\mathrm{a}}\end{array}$ & $\begin{array}{l}7.9520 \\
(1.8735)^{\mathrm{c}}\end{array}$ & $\begin{array}{l}-0.1852 \\
(-0.4398)\end{array}$ \\
\hline $\begin{array}{l}\text { 8. Cargo Preference Bill } \\
\text { Maritime Unions }\end{array}$ & $\begin{array}{c}0.3920 \\
(5.1031)^{\mathrm{a}}\end{array}$ & $\begin{array}{l}1.578 \\
(1.1375)\end{array}$ & $\begin{array}{l}0.3447 \\
(2.1379)^{\mathrm{b}}\end{array}$ \\
\hline
\end{tabular}

a Significant at the $1 \%$ level.

Significant at the $5 \%$ level

Significant at the $10 \%$ level.

dicating a Democrat, was significant at the $1 \%$ level for 5 of 7 issues. All coefficients of variables included to represent constituent preferences in the voting equations were significant at the $10 \%$ level or higher, and expected sign patterns prevailed.

Estimates for the Tobit equations explaining contributions were also quite similar for the two estimation techniques. Since the single equation Tobit estimates are consistent, this is not surprising. The contribution equations showed that, as anticipated, contributions were targeted primarily at incumbents, especially those who were members of important committees. For 6 of the 8 contributing groups studied, the coefficient for the dummy indicating an incumbent was positive and significant at the $10 \%$ level or higher. With the exception of the Teamsters, each contributing group gave significantly higher contributions to members of a related committee. The results also showed that contributors gave less to candidates who were elected by larger margins in the election. Although the theoretical discussion hypothesized that contributions would be aimed at likely winners, an explanation for this result can be offered. It is plausible that many candidates who are very likely to win simply do not solicit or accept contributions. The negative sign for the coefficient of the congressman's vote percentage may occur because vote percentage is correlated with candidate decisions not to campaign exten- sively. In the simple two-equation model of this paper, I have not taken account of the possible importance of candidate solicitation efforts. (Future work might usefully attempt to incorporate effort of solicitation into a model similar to this one.) The results also showed some tendency for groups to give along ideological lines. Business groups most often gave to conservatives, while labor groups gave to liberals. Contributions did not follow party lines very strictly, however. A number of business groups (including the banking association, the trucking association, and automobile dealers) joined with labor groups to give more contributions to Democrats. The latter finding lends credence to the "quid pro quo" hypothesis, since Democrats were probably considered more powerful by virtue of their majority party status. In addition, interest groups gave heavily to congressmen initially predisposed to vote in their favor. Dairy contributors gave to those from farming districts, oil companies gave to those from oil producing states, and maritime unions gave to those with ports in their districts. These findings suggest that the desire to maintain a systematic reward structure, or to communicate with the public by means of candidates' campaigning, may be important interest group motives.

Table 2 provides estimates of $\gamma$ (the coefficient of contributions in the equation explaining votes) and $\rho$ (the error term correlation coefficient) for 
each issue. It is apparent that the estimated effects of contributions on voting differ substantially for the two estimation techniques. According to the single equation probit estimates, contributions had positive coefficients for each of the eight contributors analyzed, and six of the coefficients were significant at the $10 \%$ level. The FIML estimates of model SPT indicate much less substantial effects of contributions; only one contribution coefficient (that of Rockwell International contributions in the B-1 bomber voting equation) retains a significant coefficient. In the voting equations for all other issues, estimated contribution coefficients were smaller than their single equation counterparts (two even had negative signs) and the estimated error term correlation coefficient was positive. The positive correlation between the error terms indicates that campaign contributions are likely to go to candidates who are likely to vote favorably on the relevant issue; hence single equation estimates of $\gamma$ are biased upwards. In five cases, a $t$-test at the $10 \%$ significance level indicates that the hypothesis of zero correlation can be rejected, so it appears that the use of the more general simultaneous model is appropriate.

\section{Conclusions}

FIML estimates of the simultaneous probitTobit model suggest that the effects of campaign contributions on voting are smaller than single equation probit estimates would indicate. We are generally unable to conclude that contributions have a significant impact on voting decisions; apparently votes are most often decided on the basis of personal ideology or the preferences of constituents. These findings differ markedly from the earlier results of Durden and Silberman, whose single equation models showed a substantial impact of contributions on voting decisions.

Despite the lack of significance according to model SPT, it would not, however, be appropriate to unambiguously conclude that contributions have no effects on voting. For six of eight coefficients the anticipated positive sign resulted, and one coefficient remained marginally significant. Inspection of table 2 also shows that the lack of significance is attributable not only to smaller coefficient size, but also to larger standard errors. The FIML estimates of the contribution coefficients are not very precise. It is probable that rather poor overall explanatory power in the equations explaining contributions leads to imprecision of these estimates in the voting equation. If better models to explain contributions are developed in the future, this might result in greater precision in estimating the effects of contributions on voting.

\section{REFERENCES}

Abrams, Burton A., "Legislative Profits and the Economic Theory of Representative Voting: An Empirical Investigation," Public Choice 31 (Fall 1977), 111-128.

Alexander, Herbert E., Money in Politics (Washington, D.C.: Public Affairs Press, 1972).

Chappell, Henry W., "The Economics of Campaign Finance: An Empirical Study,' unpublished Ph.D. dissertation, Yale University, 1979.

_, "Campaign Contributions and Voting on the Cargo Preference Bill: A Comparison of Simultaneous Models," Public Choice 36(2) (1981), 301-312.

Danielson, Albert L., and Paul H. Rubin, "An Empirical Investigation of Voting on Energy Issues," Public Choice 31 (Fall 1977), 121-128.

Durden, Gary C., and Jonathan J. Silberman, "Determining Legislative Preferences for the Minimum Wage: An Economic Approach," Journal of Political Economy 84 (Apr. 1976), 317-329.

Heckman, James J., "Simultaneous Equation Models with Continuous and Discrete Endogenous Variables and Structural Shifts," in Stephen M. Goldfeld and Richard E. Quandt (eds.), Studies in Nonlinear Estimation (Cambridge, MA: Ballinger Publishing Co., 1976).

"Dummy Endogenous Variables in a Simultaneous Equation System,"'Econometrica 46 (July 1978), 931-960.

Jackson, John E., Constituencies and Leaders in Congress (Cambridge: Harvard University Press, 1974).

Jacobson, Gary C., "The Effects of Campaign Spending in Congressional Elections," American Political Science Review 72 (June 1978), 469-491.

Johnson, Thomas, "Qualitative and Limited Dependent Variables in Economic Relationships," Econometrica 40 (May 1972), 455-462.

Kau, James B., and Paul H. Rubin, "Self Interest, Ideology, and Logrolling in Congressional Voting," Journal of Law and Economics 22 (Oct. 1979), 365-384.

Kau, James B., Donald Keenan, and Paul H. Rubin, "A General Equilibrium Model of Congressional Voting," paper presented at the American Economic Association Meetings, Atlanta, 1979.

Olsen, Randall J., "The Analysis of Models with One Continuous and One Dichotomous Dependent Variable," mimeographed, Yale University, 1975.

Palda, Kristian S., "The Effect of Expenditure on Political Success," Journal of Law and Economics 18 (Dec. 1975), 745-774.

Rose-Ackerman, Susan, Corruption: A Study in Political Economy (New York: Academic Press, 1978).

Tobin, James, "Estimation of Relationships for Limited Dependent Variables," Econometrica 26 (Jan. 1958), 24-36.

Welch, W. P., "The Economics of Campaign Funds," Public Choice 20 (Winter 1974), 83-97.

"The Allocation of Political Monies: Economic Interest Groups," Public Choice 35 (Mar. 1980), 97120.

" "Do Campaign Contributions Affect Legislative Voting? The Case of the Milk Lobby," Western Political Quarterly, forthcoming. 